\title{
Professional Development Framework for Secondary Mathematics Teachers
}

\author{
Mi Sun Park and Young Rae Kim \\ Texas A\&M University-San Antonio \\ San Antonio, TX, United States \\ Tamara J. Moore \\ Purdue University \\ West Lafayette, IN, United States \\ Terrence Wyberg \\ University of Minnesota \\ St. Paul, MN, United States
}

\begin{abstract}
Teacher professional development for mathematics teachers is critical to improving teacher quality and student achievement. This study clarifies nine core features for effective professional development programs in mathematics education, based on previous research. These features are: (1) content focus, (2) active learning, (3) fostering coherence, (4) duration, (5) collective participants, (6) teacher outcomes, (7) research-based models, (8) data driven by students, and (9) changes in teachers' beliefs and attitudes. In addition, this study provides a module of professional development programs involving all of the nine core features for mathematics teachers. The evidence concerning the effectiveness of the program is discussed. This study provides guidelines to create effective teacher professional development programs.
\end{abstract}

Keywords: training module; professional development; mathematics teachers; teacher education.

\section{Introduction}

The quality of teaching mathematics has centered on a growing national concern over the past decades (Charalambous \& Praetorius, 2018; Moyer-Packenham, Bolyard, Oh, Kridler, \& Salkind, 2006; Schlesinger \& Jentsch, 2016). Research has argued that professional development is critical to improving teacher quality and student achievement (Desimone, 2011; Desimone \& Garet, 2015). Research investigated what makes professional development effective in improving student achievement in mathematics. Recently, researchers have forged a 
remarkable level of national consensus regarding the core features of effective professional development to improve teacher quality in teaching and learning mathematics through enhancing teachers' content and pedagogical knowledge and their classroom practice to promote student achievement, such as content focus and active learning (Desimone, 2011; Egert, Fukkink, \& Eckhardt, 2018).

Still, there is a need for clear paradigms to help practicing mathematics educators develop an effective professional development program that involves agreed-upon core features (Beisiegel, Mitchell, \& Hill, 2018; Desimone \& Garet, 2015; Wayne, Yoon, Zhu, Cronen, \& Garet, 2008). In addition, few studies have provided an entire module of mathematics teacher professional development involving these core features.

This study provides a clear paradigm including the core features for effective professional development in mathematics education, with empirical evidence. First, we present a list of the core features for effective professional development in mathematics education, based on previous research. Second, we provide a module of professional development, including all of the core features for 6th8th grade mathematics teachers. Third, we provide empirical evidence of the effectiveness regarding professional development by using both quantitative and qualitative methods.

\section{Suggested Features for Effective Professional Development in Mathematics Education}

Professional development is defined as any activity intended to (a) develop teachers' knowledge, skills and expertise; and (b) prepare teachers for improved educational performance in present or future roles within a school setting (Desimone, 2009; Organization for Economic Co-operation and Development [OECD], 2009). One of the main purposes of professional development is to improve the quality of schools-to improve teaching and student learning (Desimone, 2011). Teachers can consider professional development as a vehicle for improving teaching practice, and in turn, improving student achievement. Professional development is critical to helping mathematics teachers become familiar with new methods or technologies of teaching and learning in their content areas, and keep up with the changes in standards and assessments at the district, state, and national levels.

As research begins to illuminate high-quality professional development, the core features for effective professional development, as they relate to mathematics education, have been underscored (Bransford, Brown, \& Cocking, 2000; Cohen \& Hill, 2000; Desimone, 2009; Desimone \& Garet, 2015; Desimone, Smith, \& Phillips, 2013) as follows:

(1) Content focus: Teachers need opportunities to develop well-organized bodies of content knowledge and pedagogical content knowledge of their disciplines. Thus, professional development activities should focus on subject matter content and should deepen teachers' content skills, and the ways students learn that content; 
(2) Active learning: Professional development activities should actively engage mathematics teachers in meaningful discussion with other teachers or training specialists about the goal of a lesson, tasks for students, teaching strategies, and student thinking or work, and practice;

(3) Fostering coherence: Professional development in mathematics education should be consistent with teachers' goals of what they are expecting from the professional development, and should be in alignment with the standards and assessments at the district, state, and national levels;

(4) Duration: Professional development in mathematics education should have sufficient duration, including both the span of time over which the activity is spread (e.g., one semester) and the hours of contact time (e.g., 20 hours);

(5) Collective participants: Teachers need time to work with peers together to improve their content and pedagogical content knowledge. Professional development in mathematics education should involve groups of teachers from the same school, grade level, or subject to build an interactive learning community; and

(6) Teacher outcomes: Teachers need time to reflect upon what they learn and how they can apply what they learn. Professional development in mathematics education should involve assessment tools to measure the extent of teachers' knowledge and skills, and changes in classroom teaching practice.

These features are largely recommended for effective professional development programs, but research shows that the independent presence of each feature provides little evidence of effective professional development. Therefore, we need to create professional development programs that involve all of these suggested features. In addition to the six features, three additional components that focus on teaching are worth considering for developing effective professional development programs in mathematics education, as follows.

\section{Research-Based Models}

There is no simple recipe for successfully teaching all students to improve their conceptual understanding (Graham \& Fennell, 2001; National Council for Teachers of Mathematics [NCTM], 2000; Oudman, van de Pol, Bakker, Moerbeek, \& van Gog, 2018). Teachers often bring their own experiences, backgrounds, and cultures into their classrooms, which are one of the most significant factors in improving students' learning (Ball \& Cohen, 1999; He, Lundgren, \& Pynes, 2017; Loucks-Horsley \& Matsumoto; 1999). It is essential for mathematics teachers to have experience or knowledge about new teaching skills and ways of students' thinking and understanding when working in mathematics. To support teachers with this experience and knowledge, professional development should involve research-based models and should present rationales for using new teaching strategies or applying teaching theories (Munthe \& Rogne, 2015). Mathematics teachers need to build their understanding of the relationships among research-based models involving students' thinking, as well as new strategies, teaching and learning theories, and 
their classroom practices for their students (Brouwer \& Korthagen, 2005; Rhine, 1998).

\section{Data Driven by Students}

Teaching should begin with an understanding of students' prior knowledge of mathematics and their need to learn mathematics (Shulman, 1987). Through activities, such as interviewing their students, teachers can understand their students' mathematical abilities and misconceptions in their learning of mathematics (Borko, 2004; Magen-Nagar, 2016). Understanding how their students think helps teachers gain insight into effective teaching approaches for them (Kennedy, 2016). Professional development requires that teachers understand not only how their own students best learn, but also which tasks or materials best engage them. This knowledge can help teachers gather data about their own students in order to create appropriate curricula for their classes. Effective professional development entails creating, implementing, reflecting on, and modifying teaching approaches or activities teachers learn during professional development for their own students (Kennedy, 2016; Stein, Smith, \& Silver, 1999).

\section{Changes in Teachers' Beliefs and Attitudes}

Teachers' beliefs about teaching and learning mathematics are closely related to students' mathematics learning because of their influence on teaching practices (Barkatsas \& Malone, 2005; Lui \& Bonner, 2016). Teachers' beliefs play a critical role in predicting their thinking, intentions, and practices in their classrooms (Speer, 2005). The connection between teachers' beliefs and their practices has been well established (Cohen, 1990; Eren, 2013; McMullen et al., 2006). Attitude can be defined as a function of belief (Shrigley, Koballa, \& Simpson, 1988). An attitude is "a relatively enduring organization of beliefs, feelings, and behavioral tendencies towards socially significant objects, groups, events or symbols" (Hogg \& Vaughan, 2005, p. 150).

Teachers' beliefs and attitudes influence the school environment overall, including such things as the focus of the curriculum and willingness to change (Beets, Vuchinich, Acock, Li, \& Allred, 2008; Hinde, 2003). Thus, changes in teachers' beliefs and attitudes should also be considered as a targeted outcome for effective professional development in mathematics education. Research suggests that studies of professional development should measure changes in teachers' beliefs and attitudes (Guskey, 2002; van Aalderen-Smeets \& Walma van der Molen, 2015). Teachers' beliefs and attitudes are closely related to their implementation of new teaching methods, namely the transition from professional development into their classrooms. Changes in teachers' beliefs and attitudes lead to changes in teachers' classroom practices and their behaviors, and ultimately, in the learning achievement of their students (Guskey, 2002; Wilson \& Cooney, 2003). Research has investigated how various professional programs help teachers align their beliefs and practices with new mathematics curricula that are provided in these programs (Wilson \& Cooney, 2003). Although certain professional development programs provide teachers with some ideas, they are largely superficial to mathematics teaching rather than 
fundamental to changing core beliefs and practices about mathematics and its pedagogy (Garet, Porter, Desimone, Birman, \& Yoon, 2001). Studies are required to explore changes in teachers' beliefs and attitudes as a very crucial goal through professional development. Such changes in teachers' beliefs and attitudes might be used as a better way of measuring the effectiveness of professional development (Guskey, 2002).

In sum, we identify the nine core features for effective professional development in mathematics education, based on the literature. They involve: (1) content focus, (2) opportunity for active learning, (3) fostering coherence, (4) duration, (5) collective (participation) engagement, (6) teacher outcomes, (7) researchbased models, (8) data driven by students, and (9) promoting changes in teachers' beliefs and attitudes about teaching mathematics. A paradigm for effective professional development is expected to include all of these nine core features.

\section{Professional Development Program}

This study shows what a module of effective professional development for secondary mathematics teachers, involving all of the nine core features mentioned above, looks like. Both quantitative and qualitative methods were used to investigate the effectiveness of the professional development module by examining changes in mathematics teachers' attitudes and beliefs about teaching, as well as teachers' knowledge improvement. The following section presents a theoretical framework for the professional development module used in this study.

\section{The Lesh Translation Model}

The professional development module involved teaching and learning theories and research-based models about teaching mathematics. The theoretical framework for the professional development module was mainly based on the Lesh Translation Model.

The Principles and Standards for School Mathematics (NCTM, 2000) emphasize the role of representation in learning mathematics. It asserts that students should "create and use representations to organize, record, and communicate mathematical ideas; select, apply, and translate among mathematical representations to solve problems; and use representations to model and interpret physical, social and mathematical phenomena" (p. 67). Theorists have recommended that curriculum activities and materials be presented in multiple modes in order to develop effective learning environments for each student (Lesh \& Doerr, 2003; Suh, 2007). The Lesh Translation Model (Figure 1) is a framework to represent the understanding of conceptual mathematical knowledge (Lesh \& Doerr, 2003). 


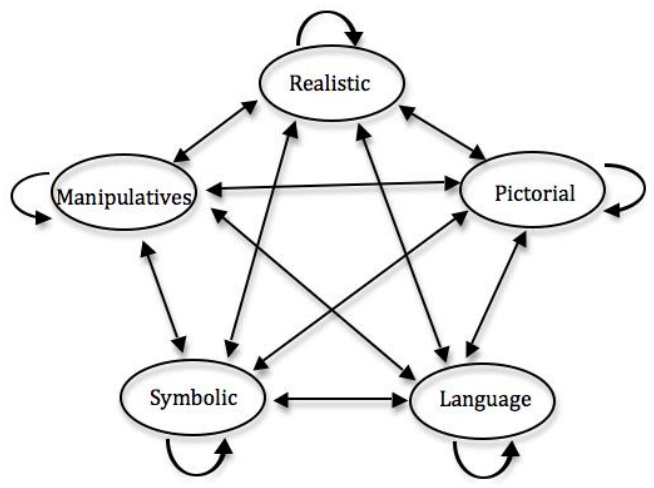

Figure 1: The Lesh Translation Model

This model consists of multiple modes of representation: 1) realistic, 2) symbolic, 3) language, 4) pictorial, and 5) manipulative (concrete, hands-on models) representation. The Lesh Translation Model emphasizes that understanding concepts lies in the ability of students to represent mathematical concepts through the five different categories of representation, and in the ability to translate not only between the multiple representations (e.g., from pictorials to the symbolic mode) but also within the same category of the representation (e.g., from a pictorial to another pictorial mode) (Cramer, 2003). This type of translation can support students' relational thinking and mathematical conceptual understanding.

The professional development program provided teachers with a variety of activities using multiple representations and interacting within and among these representations. For example, when teachers modeled the addition of fractions $\frac{2}{3}+\frac{1}{4}$ using rectangles (area models), they translated from symbolic modes to the pictorial representation. When teachers modeled the addition of fractions using rectangles and showed the same addition of fractions using a number line, they translated within the pictorial mode. Teachers gained experience in using these representations to implement them in their classrooms. The following section is a description of the professional development program. The description is followed by research evaluating the effectiveness of the professional development program.

\section{A Module for Professional Development}

Based on the theoretical framework mentioned above, a module for a five-day professional development program was created for regional 6th-8th grade mathematics teachers as they prepared their students to think more algebraically in the middle grades. The professional development program provided a total of 30 hours for content training during the school year, and a total of 16 hours for professional learning community (PLC) meetings with their mathematics team members, who participated in the training at each school (see Appendix A). The PLC meetings were led by each school facilitator, who attended three full days (nine hours) of customized training sessions, specifically focusing on Math Reasoning PLC development, strategies, and management. 
The training days focused on various activities involving how to use multiple representations in a classroom, how to interpret student thinking, and how to transfer learning from the training sessions to their own instruction. The teachers who participated in the training spent time looking at the different ways that students solve algebraic problems to develop their ability to sequence examples and lead classroom discussions, focusing on the development of algebraic ideas. Because teachers need to have a deeper understanding of the algebra they teach in order to implement the new standards, the module was created to enhance teachers' abilities: (1) to identify key learning points for various algebraic ideas; (2) to establish a repertoire of developed questioning techniques to help guide student learning; and (3) to improve the way that they listen in order to assess student thinking. The facilitators for the professional development were mathematics education specialists. They provided teachers with the benchmarks, curricula and experiences needed for students to develop algebraic reasoning and thinking by working through problems, viewing samples of students' work problems, and analyzing student work. The following Table 1 provides brief descriptions for each training day.

Table 1: Outline of the five training days for 6 th-8th grade mathematical reasoning with the rational numbers module

GOAL of Module: To create a professional development experience for mathematics teachers as they prepare their students for success in 8th-grade algebra.

\begin{tabular}{|c|c|c|}
\hline Time & Topic & Key ideas \\
\hline $\begin{array}{l}\text { Day } 1 \\
\text { (Sept) }\end{array}$ & $\begin{array}{l}\text { Making sense } \\
\text { of rational } \\
\text { numbers }\end{array}$ & $\begin{array}{l}\text { Five interpretations of fractions } \\
\text {-Participants solved problems involving fractions using } \\
\text { a variety of materials. } \\
\text {-Materials: fraction circles, paper strips, chips, and } \\
\text { number lines } \\
\text { Fraction-ordering strategies } \\
\text {-Participants used manipulatives, mental images, and } \\
\text { student work to investigate the stages that students } \\
\text { pass through as they compare and order fractions. } \\
\text {-Materials: fraction circles, paper strips, chips, and } \\
\text { number lines } \\
\text {-NCTM Process Standards: Problem Solving, } \\
\text { Representation, and Communication }\end{array}$ \\
\hline $\begin{array}{l}\text { Day } 2 \\
\text { (Nov) }\end{array}$ & $\begin{array}{l}\text { Reasoning } \\
\text { with rational } \\
\text { numbers } \\
\text { using quotient } \\
\text { interpretation }\end{array}$ & $\begin{array}{l}\text { Equal sharing problems to understand rational numbers } \\
\text { (Continued) } \\
\text {-Participants learned how to write problems, assess } \\
\text { work, and planned for future teaching related to equal } \\
\text { sharing problems. } \\
\text {-Participants focused attention on the quotient } \\
\text { interpretation of rational numbers. } \\
\text {-Materials: student work, pictures, and fraction circles } \\
\text {-Multiple group problems that are a set of problems } \\
\text { involving key mathematical ideas of fractions, and that }\end{array}$ \\
\hline
\end{tabular}




\begin{tabular}{|c|c|c|}
\hline & & $\begin{array}{l}\text { are solved by using strategies including direct } \\
\text { modeling, repeated addition, grouping and combining, } \\
\text { and multiplicatives } \\
\text {-Participants learned how to use different types of } \\
\text { problems in their classrooms to further understand } \\
\text { learning benchmarks around fractions and the } \\
\text { development of algebraic ideas. } \\
\text {-Materials: student work, fraction circles, patty paper, } \\
\text { and number lines } \\
\text {-NCTM Process Standards: Problem Solving, Reasoning } \\
\text { and Proof, Representation, and Communication }\end{array}$ \\
\hline $\begin{array}{l}\text { Day } 3 \\
\text { (Jan) }\end{array}$ & $\begin{array}{l}\text { Multiplication } \\
\text { and division } \\
\text { with rational } \\
\text { numbers }\end{array}$ & $\begin{array}{l}\text { Fraction multiplication } \\
\text {-Participants learned how number selection and model } \\
\text { choice develop the concept of multiplication and the } \\
\text { operator interpretation of rational numbers. } \\
\text {-Participants learned how fraction multiplication is } \\
\text { developed in the RNP curriculum. } \\
\text {-Materials: student work, fraction circles, patty paper, } \\
\text { and number lines } \\
\text { Fraction division } \\
\text {-Participants learned how to write measurement } \\
\text { division problems that encourage the development of } \\
\text { the same denominator algorithm for the division of } \\
\text { fractions. } \\
\text {-Participants learned how fraction division was } \\
\text { developed in the RNP curriculum. } \\
\text {-Materials: student work, fraction circles, and number } \\
\text { lines } \\
\text {-NCTM Process Standards: Problem Solving, } \\
\text { Connection, and Reasoning and Proof }\end{array}$ \\
\hline $\begin{array}{l}\text { Day } 4 \\
\text { (March) }\end{array}$ & $\begin{array}{l}\text { Unit rate and } \\
\text { algebraic } \\
\text { solutions }\end{array}$ & $\begin{array}{l}\text { MEA-Ratios and proportions } \\
\text {-Participants learned how to use the Bigfoot MEA } \\
\text { (www.region11mathandscience.org/.../Bigfoot_MEA_ } \\
\text { Teacher_Materials.doc) to develop proportional } \\
\text { reasoning skills among their students. } \\
\text {-Materials: Bigfoot MEA, student work, and measuring } \\
\text { tools } \\
\text { Developing the interpretation of rational numbers } \\
\text {-Participants learned how students reason } \\
\text { proportionally and how to increase student } \\
\text { understanding of proportionality with rational } \\
\text { numbers. } \\
\text {-Materials: student work } \\
\text {-NCTM Process Standards: Problem Solving, Reasoning } \\
\text { and Proof, Representation, and Communication }\end{array}$ \\
\hline
\end{tabular}




\begin{tabular}{|c|c|c|}
\hline $\begin{array}{l}\text { Day } 5 \\
\text { (May) }\end{array}$ & $\begin{array}{l}\text { Making sense } \\
\text { of fractions, } \\
\text { decimals, and } \\
\text { percentages }\end{array}$ & $\begin{array}{l}\text { Naming, ordering and operations involving decimals } \\
\text {-Participants learned how to name, order and perform } \\
\text { operations involving decimals by using a variety of } \\
\text { formal and informal approaches. } \\
\text {-Materials: number lines, }+ \text { /- decimal grids, crayons, } \\
\text { base-ten blocks, and student work } \\
\text {-Working with percentages } \\
\text {-Participants learned to use percent grids to make sense } \\
\text { of situations involving percentages. } \\
\text {-Materials: percent grids, number lines, and graphs } \\
\text {-NCTM Process Standards: Problem Solving, Reasoning } \\
\text { and Proof, and Representation }\end{array}$ \\
\hline
\end{tabular}

\section{An Evaluation Study}

An evaluation was conducted to examine the effectiveness of the professional development module, which was designed by one of 11 regional teacher centers, Mathematics and Science Teachers Academies (MSTA). The professional development was intended to help the regional elementary or middle school mathematics teachers meet the new requirements of algebra mastery based on the new state standards. The MSTA designed and implemented the professional development module to improve their teachers' knowledge, including both content and pedagogical knowledge, so that they could effectively implement the new state standards. This study examined not only teachers' knowledge improvement, but also changes in teachers' attitudes and beliefs about teaching.

\section{Participants}

The 263 middle-school mathematics teachers from 36 schools participated in a yearlong professional development program in mathematics for grades 6-8. A total of 236 teachers took the pre-knowledge test, and 208 mathematics teachers took the post-knowledge test. One hundred eighty mathematics teachers took both the pre- and post-knowledge tests. Two hundred thirty-five mathematics teachers took the pre-survey of instruction and the pre-teachers' beliefs interview. One hundred ninety-five and 202 mathematics teachers took the postsurvey of instruction and the post-teachers' beliefs interview, respectively. A total of 176 teachers took both the pre- and post-surveys of instruction, and 167 teachers took both the pre- and post-teachers' beliefs interviews. However, several participants failed to complete the surveys and interviews perfectly by leaving blank answers; thus, these data were removed in the statistical analyses.

\section{Data Collection}

The data involved (1) teachers' knowledge tests, including content knowledge and pedagogical knowledge; (2) attitude and self-evaluation surveys; and (3) teachers' beliefs interviews. The participants were asked to take the tests and surveys in the beginning and at the end of the professional development program to assess its impact on the development of their knowledge and change in their beliefs and attitudes. 
The knowledge tests measured teachers' understanding of rational numbers and fractions, their problem-solving abilities about rational numbers, and their teaching strategies using various representations. The knowledge tests consisted of 14 main questions in which some had three to four sub-questions (see Appendix B). The questions measured teachers' understanding of fractions, problem-solving abilities for fractions, and students' misconceptions and teaching strategies using multiple representations. All of the questions, including the sub-questions, were open-ended.

The teachers' survey of instruction was divided into four sections: (1) instructional activities in mathematics; (2) formal or informal assessment; (3) instructional influences; and (4) teachers' opinions about mathematics, teaching mathematics, and their preparedness. Teachers' beliefs were measured by using a pen-and-pencil version of the Teachers' Beliefs Interview (TBI) (Luft, Bang, \& Roehrig, 2007). We adopted three open-ended questions about teachers' instruction, such as the role of the mathematics teacher, what to teach or what not to teach, and how to maximize student learning. We observed selected teachers at the beginning, middle and end of the training, using the Oregon Teacher Observation Protocol (OTOP; Morrell, Wainwright, \& Flick, 2004). The observation data provided a big picture regarding the interactions between a teacher and her/his students, along with teaching strategies used in lessons by the teacher. They also provided limited, but useful information to explore the transition from professional development into the teacher's classroom.

The teachers recorded each PLC meeting, and they discussed what their issues were from the baseline tests and interviews with their students. We chose two schools' PLC meetings from 21 schools that had completed the PLC documents for the four days of PLC meetings and that had used the PLC report protocol we had given them.

\section{Data Analysis}

For each participant, "changed scores" were obtained by subtracting the pre achievement scores from the post achievement scores as measured by each instrument. Thus, the dependent variables were individual differences (a) between the teachers' knowledge tests ("Post knowledge test" - "Pre knowledge test"); (b) between the attitude and self-evaluation surveys ("Post-survey" "Pre-survey"); and (c) between the teachers' beliefs interviews ("Post-beliefs interview" - "Pre-beliefs interview"). To examine the effects of the professional development program, one-sample t-tests were performed to test the following hypotheses:

$$
\begin{aligned}
& H_{0}: \mu_{j}=0 \\
& H_{A}: \mu_{j} \neq 0
\end{aligned}
$$

where is a population mean of the "changed scores" as measured by $\mathrm{j}=$ knowledge test, attitude and self-evaluation survey, and beliefs interview The analyses were also conducted for each question in each instrument. If there was evidence to reject the null hypotheses (using an alpha-level of 0.05), we would have evidence that there were significant changes in the participant achievement scores after the professional development program. 
In addition, the PLC documents allowed us to look at what they learned about teaching and their students. We also discussed how the teachers understood their students' understanding, based on their students' interviews.

\section{Results: Knowledge test}

The questions examining the teachers' content knowledge for Algebra 6-8 focused on their conceptual understanding of algebraic content, such as rational numbers/fractions, equivalent fractions, visual representations of rational numbers, language representations, and problem solving (see Appendix B). The overall results from the measure for teachers' knowledge, including both mathematical content and pedagogical knowledge, showed that this professional development program resulted in significant improvement $(t(179)=-20.264$, $p<0.05)$. For the question about writing "the definition of a rational number," the teachers were better at defining a rational number in the post-test $(t(179)=-5.021$, $p<0.05)$, but many teachers still revealed a lack of strategies in explaining the term effectively (Pre: $7.6 \%$ out of 180 teachers presented a correct response, versus Post: $23.6 \%$ ). The teachers still had not figured out "a rational number that is not expressed by a fraction" $(t(179)=-1.327, p=0.186)$ in the pre- and posttests. However, most of the teachers could "give examples of a fraction that is not expressed by a rational number" $(t(179)=-12.237, p<0.05)$. Pre: $43.2 \%$ out of 180 teachers presented a correct response, versus Post: $93.8 \%$. In addition, the teachers showed their abilities and meaningful strategies effectively in drawing pictures to explain rational number concepts on the post-test, compared to the pre-test $(t(179)=-5.187, p<0.05)$, using area models or number lines. However, they still exhibited a lack of strategies in explaining a picture for the multiplication and division of two fractions on a number line or any models, even though they had significantly improved. Figure 2 shows some examples from a participant's pre- and post-tests.

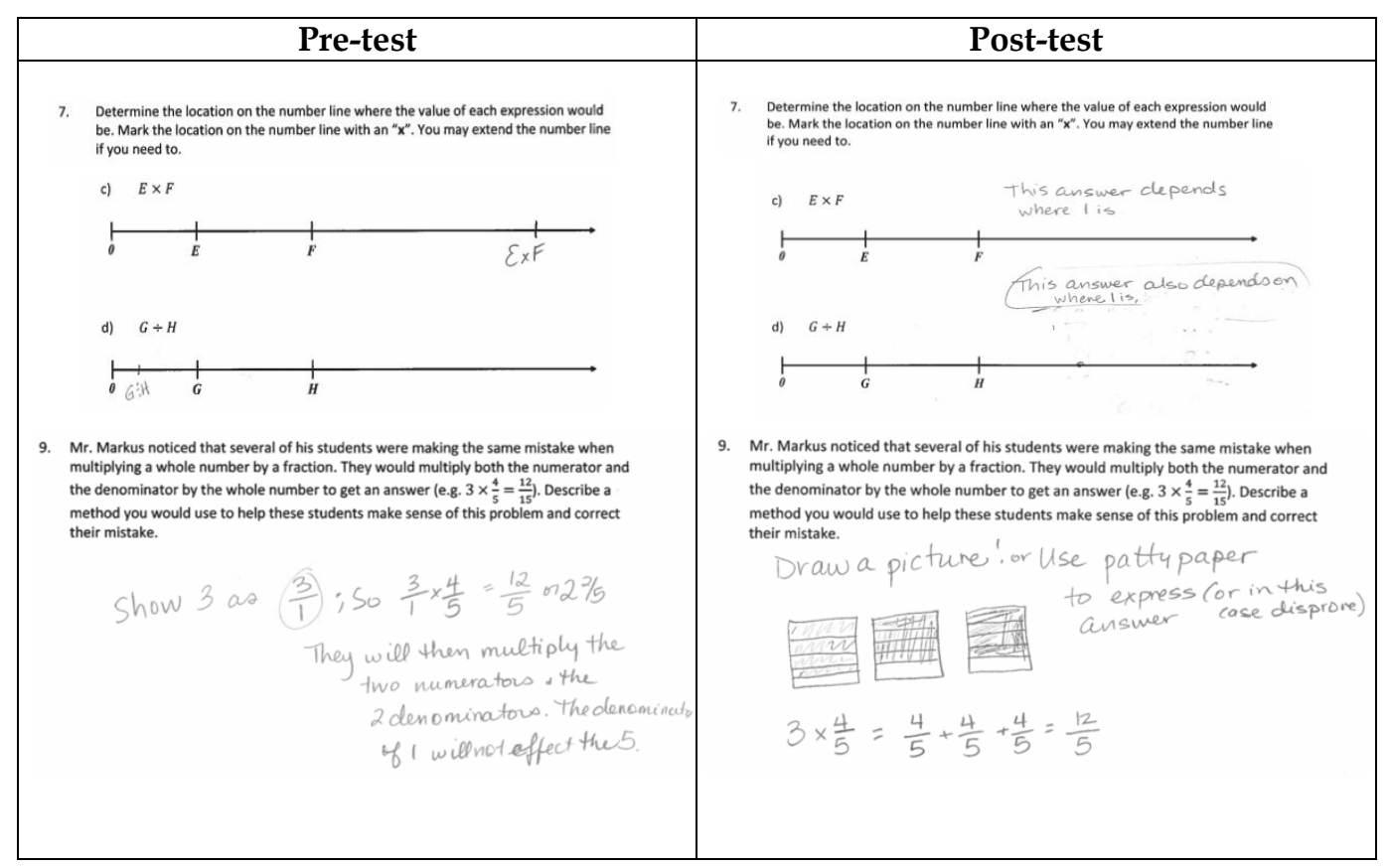

Figure 2: Samples of a participant's answers 
On the other hand, the teachers showed their abilities effectively to generate real-world problems for the multiplication and division of two fractions on the post-test, compared to the pre-test $(t(179)=-4.187, p<0.05)$. These results may indicate that the teachers developed a deeper understanding of rational number concepts and also used more correct language to explain the mathematical concepts on the post-test, compared to the pre-test. Thus, this may be evidence that they could effectively explain mathematical concepts to their students in order to improve their students' achievement in Algebra.

\section{Results: Attitudes}

According to the results from the four Likert-type scale surveys, there were statistically significant differences between the pre- and post-surveys in four out of ten questions about the instructional activities in mathematics. For example, they considered "applying mathematical concepts to real-world problems" $(t(173)=-1.996, p<0.05)$, "presenting math ideas using symbols" $(t(172)=-2.002$, $p<0.05)$, "using manipulatives" $(t(173)=-2.617, p<0.05)$, and "connecting different representations (e.g., manipulatives, math symbols, real-world situations, etc.) to understand mathematical concepts" $(t(173)=-2.843, p<0.05)$ more in the postsurvey, compared to the pre-survey. In both the pre- and post-surveys, more than $57 \%$ of teachers answered that they used more than $25 \%$ of their instruction time during the school year for real-world situations, language, symbols, and pictures. However, only 44 teachers in the pre-survey and 55 out of 174 teachers in the post-survey responded that they used more than $25 \%$ of their instruction time during the school year for manipulatives (e.g., hands-on activities), even though they had statistically increased their instructional time in using manipulatives $(t(173)=-2.617, p<0.05)$. Most teachers also responded that they spent $26-50 \%$ of their instructional time during the school year using textbooks for classroom activities, in both the pre-and post-surveys. For using technology, most teachers answered that they used some (11-25\%) of their instruction time during the school year in the pre- and post-surveys.

For formal or informal assessments, the teachers showed significant differences between the pre- and post-surveys in the questions about using "symbolic representations" $(t(166)=-3.075, p<0.05)$ and "connection of mathematics ideas" $(t(170)=-2.914, p<0.05)$ with various representations when assessing students in their classes. In other types of assessments, such as "short-answer questions," "extended response questions," "pictorial representations (e.g., graphs) of information to understand concepts," and "applying math concepts to other subjects," as well as "performance tasks or events (e.g., hands-on activities)," most teachers responded that they used these activities more than once a month in both the pre-and post-surveys. However, only half of the teachers answered that they used "mathematics projects related to real-world contexts (e.g., modeling activities) and individual or group presentations (language representation)" more than once a month for student assessments, in both the pre- and post-surveys. 
Results: Teachers' self-evaluation about professional development

In instructional influence, there were statistically significant differences between the pre-and post-survey questions about the impacts on "textbooks/instructional materials" $(t(173)=2.173, p<0.05)$ and "research (e.g., Rational Number Projects)" $(t(172)=-3.248, p<0.05)$. More than $78 \%$ of teachers answered that they had been influenced by national or state mathematics education standards, their district's curriculum framework, state or district tests or results, their experience in pre-service preparation or in their classrooms, their students' special needs or interests, their students' prior knowledge levels, and their professional development training of what they teach in their class, in both the pre-and post-surveys.

The most significant differences between the pre- and post-surveys were in all of the items that asked how well they were prepared to teach algebra. The items pertained to their preparation about teaching "Algebra reasoning" $(t(171)=$ $3.096, p<0.05)$, "Ratios and proportions" $(t(171)=-4.369, p<0.05)$, "Algebra representation" $(t(171)=-2.947, p<0.05)$, and "Problem solving and modeling" $(t(171)=-3.465, p<0.05)$. The teachers also felt they were well prepared to teach mathematics with multiple representations, such as "real-world situations" $(t(171)=-3.548, \quad p<0.05)$, "language" $(t(164)=-4.572, \quad p<0.05)$, "manipulatives" $(t(171)=-4.428, p<0.05)$, "symbols" $(t(170)=-3.631, p<0.05)$, "pictorials" $(t(171)=-$ $4.460, p<0.05)$, and "connecting those representations to teach a mathematics concept" $(t(171)=-4.851, p<0.05)$.

According to the results from the surveys for teachers' thoughts about the impact of the professional development, they emphatically described this training as giving them "a deeper understanding in mathematical representations, especially visual representations (e.g., number lines, graphs, and tables)," "meaningful discussions with other teachers," "different ways to look at certain ways/strategies of math," "different ways to teach concepts," "ideas, technologies, and strategies," "different ways to use to solve problems," "think more manipulatively," and "understanding thinking strategies of my students." The teachers also emphasized that "weekly PLC meetings where [they] discuss assessment results, instructional strategies, and student interviews" were very useful for improving their teaching of mathematics. One of the teachers also said, "The collaboration and conversation in the PLCs and during the training days have been invaluable."

\section{Results: Teacher beliefs}

The questions in the teachers' beliefs interviews concerned: (Q1) what the math teacher's role is; (Q2) what to teach or not; and (Q3) how to maximize student learning. Through analyzing the results of the teachers' beliefs interviews, we found positive changes in teachers' beliefs about their teaching mathematics. There was significant movement from a teacher-centered (code 1) to a studentcentered approach (code 5) (Q1: $t(159)=-8.151, p<0.05$; Q2: $t(162)=-4.429, p<0.05$; Q3: $t(159)=-5.423, p<0.05)$. According to the responses from the beliefs interviews, the results from all of the three questions showed that teachers moved toward the student-centered approach. In the post-interview, the 
teachers considered the students' abilities or levels more and the students' interest in learning mathematics, rather than the contents or the content sequence. The teachers also emphasized multiple representations to maximize student learning and the development of students' conceptual understanding in their post-interviews.

\section{Student data from PLC documents}

In the PLC documents, the teachers addressed questions about "what they learned about teaching," and "what they learned about our students" after the baseline assessments and students' interviews. The teachers discussed the needs of different teaching strategies for their own students. The following PLC notes showed some examples of how the teachers discussed their own student learning and the need for teaching strategies with respect to their future students, based on their student interviews.

Day 2 (1/16): PLC meeting

Our students progressively did better comparing sixth to seventh to eighth grades. But when looking from baseline to summative in a few grades...baseline in the same cases was better! We need to be sure next year to fit this better in the curriculum.

Students need more work with the number line. Most know that $3 / 5=6 / 10$, but to show it linearly was a challenge.

Day 3 (2/8): PLC meeting

We need to take a close look at seventh and eighth grades. We gained very useful knowledge on how to show pictures and make multiplying and dividing fractions more relevant to students to better understand concepts. Not just memorizing processes. This wasn't done in the past, so we need to be sure to revisit fractions across the school.

The PLC meetings between training days helped the teachers understand students' needs and additional information for the next year's math classes.

\section{Discussion and Implications}

As shown above, the results from both the qualitative and quantitative data analyses provide empirical evidence for the effectiveness of the professional development module implemented in the MSTA project. In this section, we discuss the results and demonstrate how the MSTA professional development module involves all of the nine core features of the framework for effective professional development that we synthesized, based on prior research. We also provide some implications for professional development.

\section{Content Focus}

Professional development needs to help teachers improve their content knowledge of the subjects they teach, and their pedagogical knowledge of their discipline (Ball, Hill, \& Bass, 2005; Desimone, 2011; Egert et al., 2018). Thus, all activities in a teacher professional development program need to focus on the subjects that the participants teach in order to increase their effectiveness. The MSTA professional development module for 6 th- 8 th grade mathematics teachers 
focused on mathematical reasoning with rational numbers, which is emphasized in the national and state curricula, and which is recognized as a difficult content area for students (Kim \& Park, 2018; National Mathematics Advisory Panel [NMAP], 2008). The professional development module provided various materials and activities (e.g., fraction circles or modeling activities) to teach these concepts. Each training session presented samples of students' work; the teachers discussed how they understood the students' work, and how they could teach it in a better way. Based on the results in this study, we identified that this feature is fully effective for improving teachers' content knowledge and pedagogical knowledge. First, we found that the teachers were better able to explain important mathematical concepts using multiple mathematical representations on the post-test versus on the pre-test. They found students' misconceptions and misunderstandings, and then chose methods to help students repair them, develop their understanding of the concepts, and solve mathematics problems related to the concepts. Second, the responses to the teachers' beliefs surveys show that the teachers felt more comfortable about making their instruction more student-centered, with a focus on problem solving that stimulates students' own line of inquiry. The results from the survey questions about teachers' preparation show that the teachers felt well prepared to teach rational numbers, as well as algebra, with many teaching strategies at the end of the training.

As teachers improve their content knowledge and pedagogical knowledge (e.g., teaching strategies) about particular concepts (e.g., rational numbers), they seem to gain confidence to teach broader concepts (e.g., algebra). Thus, professional development needs to be well organized in content that teachers need to teach in their class (Ball et al., 2005; Desimone, 2011). Various materials and activities need to be presented in ways to help teachers understand and teach them. Moreover, teachers need to have opportunities to look at students' work, including their misconceptions and their ways of understanding mathematical concepts through professional development (Kent, 2015).

\section{Active Learning}

Through professional development, teachers need to have opportunities to actively discuss with other teachers regarding their teaching goals, teaching strategies, students' work and thinking, and classroom practices (French, 1997; Richardson, 1998). These meaningful discussions can help teachers improve their lesson plans and their content knowledge, as well as their pedagogical knowledge. In the surveys, the teachers said they had "helpful mathematical conversations about methods and curriculum with peers." They also felt that this training "opened a lot of discussion about different ways to think about solving problems with fractions." These discussions gave the teachers "another perspective to use" something in their classes. Many teachers also mentioned the collaboration and conversation in "weekly PLC meetings, where discussed assessment results, instructional strategies, and student interviews" had been invaluable. Active discussion in professional development provides teachers with opportunities to think about their own teaching strategies and to learn new strategies from other teachers (Garet et al., 2001; Joyce \& Showers, 2002). 


\section{Fostering Coherence}

Professional development needs to rise up to teachers' expectations about professional development; moreover, it needs to be consistent with the standards and assessment that they use (Odden, Archibald, Fermanich, \& Gallagher, 2002). The MSTA professional development module involved the contents of the NCTM standards that emphasize improving students' achievement, such as problem solving, representation, reasoning and proof, and communication. In the surveys, the teachers mentioned that they enhanced their skills in these areas, and they looked at "where the teaching strategies and activities could be implemented in their curriculum."

Moreover, according to the responses to the survey questions, which asked what they wanted out of their experience with the professional development program in the beginning of the training, they wanted to become better teachers in engaging their students, and in improving their content knowledge and pedagogical content knowledge, discussion skills, and conceptual understanding for teaching. They also expected to have various teaching strategies and new methods and activities, including hands-on activities; furthermore, they sought to understand ways of students' thinking when learning mathematics and types of students' misconceptions. At the end of the training, the teachers responded that they had learned the things they wanted from the professional development. The teachers especially emphasized that they became stronger, knowledgeable mathematics teachers. They also responded that they were well prepared to teach rational numbers, as well as algebra, in the post-survey. As a result, the MSTA professional development module allowed the teachers to meet their expectations from a professional development standpoint.

\section{Duration}

Professional development needs to provide teachers with sufficient duration within a span of time and hours of contact time (French, 1997; Garet et al., 2001). However, we could not determine an ideal duration for a professional development program because it might be case by case. In this study, we could use this as a case, which might be an example for developing a professional development program. On average, the MSTA professional development module provided 46 contact hours for teachers during the school year. The hours were divided into 30 hours of content training and 16 hours of PLC meetings during the school year. This duration of MSTA professional development might be one of the reasons for explaining the positive impacts of professional development.

\section{Collective (Participation)}

Professional development needs to provide teachers with opportunities to work with colleagues from the same school, grade level, or subject to build an interactive learning community (Garet et al., 2001; Richardson, 1998). The MSTA professional development module involved two types of meetings: (1) the meetings during the training; and (2) the PLC meetings at each school. In the 
training, the teachers could meet mathematics teams from different schools, but based in the same region and the same grade levels in mathematics subjects. This meeting was a good chance to discuss different teaching strategies from different schools, and the mathematics concepts they teach. In the PLC meetings, the teachers could meet their mathematics teams from the same school and the same grade level, where they could discuss their own students' understanding of mathematics concepts, their own students' work on assessment tasks, and effective instruction for their students. The results from the surveys used in this study showed that these two meetings yielded meaningful impacts of professional development for the teachers. In addition, the teachers thought that they developed a deeper understanding about mathematical contents and their students through both types of meetings. This feedback from the teachers is good evidence in support of collective participation for effective professional development.

\section{Teacher Outcomes}

Professional development programs need to provide teachers with opportunities to reflect on what they have learned, and how they can apply what they learn. Professional development needs to have assessment tools to measure the improvement of teachers' knowledge and skills, and changes in beliefs, attitudes, and practices (Joyce \& Showers, 2002). The MSTA professional development module involved teachers' knowledge assessments, attitude and opinion surveys of instruction, and beliefs interviews in the beginning and at the end of the training. In the post-assessment, the teachers reflected upon what they learned and how they could apply it in mathematics concepts and problem solving. For example, on the post-content test, the teachers showed different teaching strategies from the pre-content test, such as when they tried to explain math concepts using various mathematical representations, such as area models or number lines, which were provided during the training to explain the concept of fractions. They were also given opportunities to think about what their beliefs, attitudes, and opinions were in regard to teaching mathematics or mathematics itself. It was very important for the teachers to think about what they had learned from the professional development, and what they still needed in the future.

\section{Research-Based Models}

The MSTA professional development module was designed based on the Lesh Translation Model to develop curriculum materials, activities, and classroom instruction. The Lesh Translation Model is a framework to represent the understanding of conceptual mathematical knowledge (Lesh \& Doerr, 2003). It consists of multiple modes of representation: 1) realistic, 2) symbolic, 3) language, 4) pictorial, and 5) manipulative representations. In the surveys, the teachers showed how they realized the importance of using multiple representations through the training. They also showed how they improved their knowledge and skills in using multiple representations to explain rational number concepts and to solve rational number problems. Research has developed teaching models using multiple mathematical representations, and research has also provided samples of students' work in these models (e.g., the 
Rational Number Project based on the Lesh Translation Model as a theoretical foundation; http://www.cehd.umn.edu/ci/rationalnumberproject/). If professional development programs use research-based models, teachers can gain experience in a variety of activities that have been verified by research (Munthe \& Rogne, 2015). Thus, using research-based models seems to increase the possibility for effective professional development.

\section{Data Driven by Students}

Teachers need to know their own students' prior knowledge and abilities for their effective teaching (Kennedy, 2016). While the teachers conducted student interviews to figure out how their students developed their understanding of mathematical concepts, they recognized what their students needed in order to master math in their grades, and how they could change their teaching approaches. They also discussed how to improve their lessons for their future students. These discussions helped teachers improve their pedagogical knowledge for their students.

\section{Changes in Teachers' Beliefs and Attitudes}

Teachers' beliefs and attitudes are closely related to teachers' classroom practices and students' learning (Cohen, 1990; Eren, 2013; Speer, 2005). Through the MSTA professional development, the teachers moved to student-centered teaching, and many teachers thought they needed to translate among multiple representations to promote students' conceptual understanding. The teachers' beliefs and their practices became more in line with the Lesh Translation Model, which was the framework for the professional development.

As shown above, the MSTA professional development module used in this study was created with consideration of all of the nine features. We could find positive impacts of the professional development on teachers' knowledge, teaching strategies, beliefs and attitudes. These features are critical components in developing effective professional development. Moreover, they should be considered in creating a teacher education curriculum for pre-service teachers, as well.

\section{Conclusions}

A paradigm for developing effective professional development in mathematics education has been reorganized, based on previous research. It involves nine components: (1) a content focus, (2) an opportunity for active learning, (3) fostering coherence, (4) duration, (5) collective (participation), (6) teacher outcomes, (7) a research-based model, (8) data driven by students, and (9) leading changes in teachers' beliefs and attitudes about teaching mathematics. This paradigm can help educators develop effective professional development for targeted groups, and can be used to evaluate the effectiveness of professional development. 


\section{References}

Ball, D. L., \& Cohen, D. K. (1999). Developing practice, developing practitioners: Toward a practice-based theory of professional education. In L. Darling-Hammond, \& G. Sykes (Eds.), Teaching as the Learning Profession: Handbook of Policy and Practice (pp. 3-32). San Francisco, CA: Jossey-Bass.

Ball, D. L., Hill, H. C, \& Bass, H. (2005). Knowing mathematics for teaching: Who knows mathematics well enough to teach third grade, and how can we decide? American Educator, 30(3), 14-17, 20-22, 43-46.

Barkatsas, A., \& Malone, J. (2005). A typology of mathematics teachers' beliefs about teaching and learning mathematics and instructional practices. Mathematics Education Research Journal, 17(2), 69-90. https:/ / doi.org/10.1007/BF03217416

Beets, M. W., Flay, B. R., Vuchinich, S., Acock, A. C., Li, K., \& Allred, C. (2008). School climate and teachers' beliefs and attitudes associated with implementation of the positive action program: A diffusion of innovations model. Prevention Science, 9(4), 264-275. https://doi.org/10.1007/s11121-008-0100-2

Beisiegel, M., Mitchell, R., \& Hill, H. C. (2018). The design of video-based professional development: An exploratory experiment intended to identify effective features. Journal of Teacher Education, 69(1), 69-89. https:// doi.org/10.1177/0022487117705096

Borko, H. (2004). Professional development and teacher learning: Mapping the terrain. Educational Researcher, 33(8), 3-15. https://doi.org/10.3102/0013189X033008003

Bransford, J., Brown, A., \& Cocking, R. (2000). How people learn: Brain, mind, experience, and school. Washington, DC: National Research Council.

Brouwer, N., \& Korthagen, F. (2005). Can teacher education make a difference? American Educational Research Journal, 42(1), 153-224. https://doi.org/10.3102/00028312042001153

Charalambous, C. Y., \& Praetorius, A. K. (2018). Studying mathematics instruction through different lenses: Setting the ground for understanding instructional quality more comprehensively. ZDM, 50(3), 355-366. https://doi.org/10.1007/s11858-018-0914-8

Cohen, D. (1990). A revolution in one classroom: The case of Mrs. Oublier. Education Evaluation and Policy Analysis, 12(3), 311-329. https://doi.org/10.3102/01623737012003311

Cohen, D., \& Hill, H. (2000). Instructional policy and classroom performance: The mathematics reform in California. The Teachers College Record, 102(2), 294-343. https:// doi.org/10.1111/0161-4681.00057

Cramer, K. (2003). Using a translation model for curriculum development and classroom instruction. In R. Lesh \& H. M. Doerr (Eds.), Beyond constructivism: Models and modeling perspectives on mathematics problem solving, learning, and teaching (pp. 449463). Mahwah, NJ: Lawrence Erlbaum Associates.

Desimone, L. M. (2009). Improving impact studies of teachers' professional development: Toward better conceptualizations and measures. Educational Researcher, 38(3), 181-199. https:// doi.org/10.3102/0013189X08331140

Desimone, L. M. (2011). A primer on effective professional development. Phi Delta Kappan, 92(6), 68-71. https:// doi.org/10.1177/003172171109200616

Desimone, L. M., \& Garet, M. S. (2015). Best practices in teachers' professional development in the United States. Psychology, Society, and Education, 7(3), 252263. http://dx.doi.org/10.25115/psye.v7i3.515

Desimone, L. M., Smith, T. M., \& Phillips, K. J. R. (2013). Linking student achievement growth to professional development participation and changes in instruction: A 
longitudinal study of elementary students and teachers in Title I schools.

Teachers College Record, 115(5), 1-46.

Egert, F., Fukkink, R. G., \& Eckhardt, A. G. (2018). Impact of in-service professional development programs for early childhood teachers on quality ratings and child outcomes: A meta-analysis. Review of Educational Research, 88(3), 401-433. https://doi.org/10.3102/0034654317751918

Eren, A. (2013). Prospective teachers' conceptions of assessment and efficacy beliefs: Values and practices. Education and Science, 38(170), 19-30.

French, V. W. (1997). Teachers must be learners, too: Professional development and national teaching standards. NASSP Bulletin, 81(585), 38-44. https://doi.org/10.1177/019263659708158507

Garet, M. S., Porter, A. C., Desimone, L., Birman, B. F., \& Yoon, K. S. (2001). What makes professional development effective? Results from a national sample of teachers. American Educational Research Journal, 38(4), 915-945. https://doi.org/10.3102/00028312038004915

Graham, K. J., \& Fennell, F. S. (2001). Principles and standards for school mathematics and teacher education: Preparing and empowering teachers. School Science and Mathematics, 101(6), 319-327. https://doi.org/10.1111/j.1949-8594.2001.tb17963.x

Guskey, T. R. (2002). Professional development and teacher change. Teachers and Teaching: Theory and Practice, 8(3), 381-391. https://doi.org/10.1080/135406002100000512

He, Y., Lundgren, K., \& Pynes, P. (2017). Impact of short-term study abroad program: Inservice teachers' development of intercultural competence and pedagogical beliefs. Teaching and Teacher Education, 66, 147-157. https://doi.org/10.1016/j.tate.2017.04.012

Hinde, E. (2003). Reflections on reform: A former teacher looks at school change and the factors that shape it. The Teachers College Record (Online only). http://www.tcrecord.org/ Content.asp?ContentID $=11183$.

Hogg, M., \& Vaughan, G. (2005). Social psychology (4th ed). London: Prentice-Hall.

Joyce, B., \& Showers, B. (2002). Student achievement through staff development (3rd ed). Alexandria, VA: Association for Supervision and Curriculum Development.

Kennedy, M. M. (2016). How does professional development improve teaching? Review of Educational Research, 86(4), 945-980. https://doi.org/10.3102/0034654315626800

Kent, L. B. (2015). Change in the era of common core standards: A mathematics teacher's journey. International Journal of Learning, Teaching and Educational Research, 12(2), 48-63.

Kim, Y. R., \& Park, M. S. (2018). The persistent difficulty of early fraction ideas in early secondary school mathematics. Journal of Education and Practice, 9(29), 32-42.

Lesh, R. \& Doerr, H. M. (2003). Foundations of a models and modeling perspective on mathematics teaching, learning and problem solving. In R. Lesh \& H. M. Doerr (Eds.), Beyond constructivism: Models and modeling perspectives on mathematics problem solving, learning, and teaching (pp. 3-33). Mahwah, NJ: Lawrence Erlbaum Associates.

Loucks-Horsley, S., \& Matsumoto, C. (1999). Research on professional development for teachers of mathematics and science: The state of the scene. School Science and Mathematics, 99(5), 258-271. https://doi.org/10.1111/j.1949-8594.1999.tb17484.x

Luft, J. A., Bang, E., \& Roehrig, G. H. (2007). Supporting beginning science teachers. Science Teacher, 74(5), 24-29. 
Lui, A. M., \& Bonner, S. M. (2016). Preservice and inservice teachers' knowledge, beliefs, and instructional planning in primary school mathematics. Teaching and Teacher Education, 56, 1-13. https://doi.org/10.1016/j.tate.2016.01.015

Magen-Nagar, N. (2016). Examining Teaching Based on Errors in Mathematics Amongst Pupils with Learning Disabilities. European Journal of Science and Mathematics Education, 4(4), 506-522.

McMullen, M. B., Elicker, J., Goetze, G., Huang, H. H., Lee, S. M., Mathers, C., Wen, X., \& Yang, H. (2006). Using collaborative assessment to examine the relationship between self-reported beliefs and the documentable practices of preschool teachers. Early Childhood Education Journal, 34(1), 81-91. https:// doi.org/10.1007/s10643-006-0081-3

Morrell, P. D., Wainwright, C., \& Flick, L. (2004). Reform teaching strategies used by student teachers. School Science and Mathematics, 104(5), 199-213. https:// doi.org/10.1111/j.1949-8594.2004.tb18243.x

Moyer-Packenham, P. S., Bolyard, J. J., Oh, H., Kridler, P., \& Salkind, G. (2006). Representations of teacher quality, quantity, and diversity in a national mathematics and science program. Journal of Educational Research $\mathcal{E}$ Policy Studies, 6(2), 1-40.

Munthe, E., \& Rogne, M. (2015). Research based teacher education. Teaching and teacher education, 46, 17-24. https://doi.org/10.1016/j.tate.2014.10.006

National Council for Teachers of Mathematics (NCTM). (2000). Principles and standards for school mathematics. Reston, VA: Author.

National Mathematics Advisory Panel (NMAP). (2008). Foundations for success: The final report of the national mathematics advisory panel. Washington D.C.: U.S. Department of Education.

Odden, A., Archibald, S., Fermanich, M., \& Gallagher, H. A. (2002). A cost framework for professional development. Journal of Educational Finance, 28(1), 51-74.

Organization for Economic Co-operation and Development (OECD). (2009). Teaching and learning international survey (TALIS). Paris: OECD.

Oudman, S., van de Pol, J., Bakker, A., Moerbeek, M., \& van Gog, T. (2018). Effects of different cue types on the accuracy of primary school teachers' judgments of students' mathematical understanding. Teaching and Teacher Education, 76, 214226. https:// doi.org/10.1016/j.tate.2018.02.007

Rhine, S. (1998). The role of research and teachers' knowledge base in professional development. Educational Researcher, 27(5), 27-31. https://doi.org/10.3102/0013189X027005027

Richardson, J. (1998). We're All Here to Learn. Journal of Staff Development, 19(4), 49-55.

Schlesinger, L., \& Jentsch, A. (2016). Theoretical and methodological challenges in measuring instructional quality in mathematics education using classroom observations. ZDM, 48(1-2), 29-40. https://doi.org/10.1007/s11858-016-0765-0

Shrigley, R. L., Koballa Jr., T. R., \& Simpson, R. D. (1988). Defining attitude for science educators. Journal of Research in Science Teaching, 25(8), 659-678. https://doi.org/10.1002/tea.3660250805

Shulman, L. (1987). Knowledge and teaching: Foundations of the new reform. Harvard Educational Review, 57(1), 1-23. https://doi.org/10.17763/haer.57.1.j463w79r56455411

Speer, N. M. (2005). Issues of methods and theory in the study of mathematics teachers' professed and attributed beliefs. Educational Studies in Mathematics, 58(3), 361391. https://doi.org/10.1007/s10649-005-2745-0

Stein, M. K., Smith, M. S., \& Silver, E. A. (1999). The development of professional developers: Learning to assist teachers in new settings in new ways. Harvard 
Educational Review, 69(3), 237-270.

https:// doi.org/10.17763/haer.69.3.h2267130727v6878

Suh, J. M. (2007). Tying it all together: Classroom practices that promote mathematical proficiency for all students. Teaching Children Mathematics, 14(3), 163-169.

van Aalderen-Smeets, S. I., \& Walma van der Molen, J. H. (2015). Improving primary teachers' attitudes toward science by attitude-focused professional development. Journal of research in science teaching, 52(5), 710-734.

https://doi.org/10.1002/tea.21218

Wayne, A. J., Yoon, K. S., Zhu, P., Cronen, S., \& Garet, M. S. (2008). Experimenting with teacher professional development: Motives and methods. Educational Researcher, 37(8), 469-479. https://doi.org/10.3102/0013189X08327154

Wilson, M. R., \& Cooney, T. (2003). Mathematics teacher change and development: The role of beliefs. In G. Leder, E. Pehkonen, \& G. Toemer (Eds.), Beliefs: A hidden variable in mathematics education? (pp. 127-147). Dordrecht, The Netherlands: Kluwer. 


\section{Appendix A}

General Outline for the Four PLC Meetings Between Training Days.

\begin{tabular}{|l|l|}
\hline PLC & Key Activity \\
\hline Meeting 1 & $\begin{array}{l}\text { Baseline Data } \\
\text {-The teachers gave their students a short series of problems to assess } \\
\text { baseline knowledge of the topic from the previous training day. } \\
\text {-The teachers shared their results, compared student strategies, and } \\
\text { planned future instruction for their students. }\end{array}$ \\
\hline Meeting 2 & $\begin{array}{l}\text { Teaching Sequence } \\
\text {-The teachers used instructional strategies with their students and } \\
\text { collected examples of students' work before the second meeting. } \\
\text {-Two components that were emphasized in the sample lessons included } \\
\text { student-to-student communication and informal assessment techniques. }\end{array}$ \\
& $\begin{array}{l}\text {-The teachers reflected on how the instructional strategies worked with } \\
\text { their students during the second meeting. }\end{array}$ \\
\hline Meeting 3 & $\begin{array}{l}\text { Teaching Interview } \\
\text {-The teachers interviewed several of their students before the third } \\
\text { meeting to assess their level of thinking and then used questioning } \\
\text { techniques to push students' thinking to a higher level. }\end{array}$ \\
\hline Meeting 4 & $\begin{array}{l}\text { Summative Assessment } \\
\text {-The teachers gave a short summative assessment to all of their students. } \\
\text {-The teachers shared the results of the assessment and discussed how it } \\
\text { would influence their future teaching of this topic. } \\
\text {-They discussed intervention strategies for students who did poorly and } \\
\text { compared student strategies. }\end{array}$ \\
\hline
\end{tabular}




\section{Appendix B}

Teachers' Knowledge Test

1. a) Write a definition of a rational number.

b) Write a fraction that is not a rational number.

c) Write a rational number that is not a fraction.

2. Write the value of each expression as one number.
a) $\frac{3}{4}+\frac{5}{12}$
b) $3 \frac{1}{4}-2 \frac{2}{3}$
c) $3 \frac{1}{2} \times 2 \frac{7}{8}$
d) $\frac{1}{3} \div \frac{5}{6}$

3. Strip A is shown below. Strip A is $\frac{3}{4}$ of the length of Strip B. Sketch Strip B.

\section{$\boldsymbol{A}$}

4. Determine the location on the number line where the value of each expression woul be. Mark the location on the number line with an " $x$ ". You may extend the number li if you need to.

a) $\quad A+B$

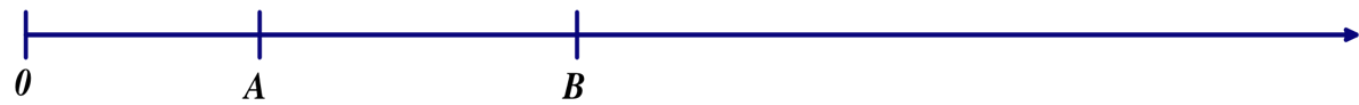

b) $\quad C-D$

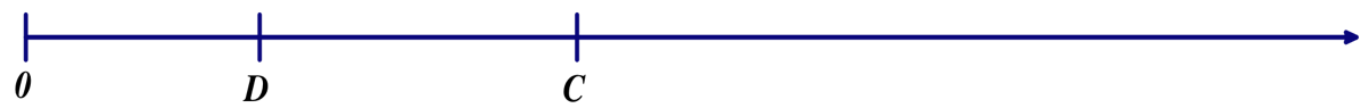

c) $E \times F$

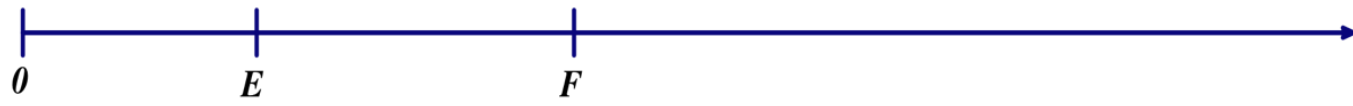

d) $G \div H$

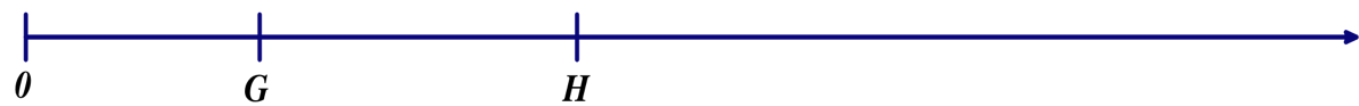


5. Explain why fractions cannot be added as described by Wayne (sixth-grade student). "On my test I had $\frac{1}{3}+\frac{2}{5}=\frac{3}{8}$ and you marked it wrong. But last Saturday our baseball team played a double header, and in the first game I was at bat three times and got one hit and in the second game I was up five times and got two hits, and my batting average for the day was $\frac{3}{8}$. So how come $\frac{1}{3}+\frac{2}{5}=\frac{3}{8}$ in baseball but not in math class?"

6. A seventh-grade student (Stella) says that $\frac{2}{5}$ is larger than $\frac{3}{8}$ because the difference between the numerator and denominator of $\frac{2}{5}(5-2=3)$ is smaller than for $\frac{3}{8}(8-3=5)$. She goes on to say that the bigger the difference between the numerator and denominator the smaller the fraction. Will her procedure always work? Explain why or why not.

7. Alison was trying to add fractions $\left(\frac{2}{3}+\frac{1}{4}\right)$ using grid paper. She chose to use a three by four rectangle to compute the sum. She shaded 8 of the 12 squares to represent the two-thirds, then one of the remaining four squares to represent one-fourth.

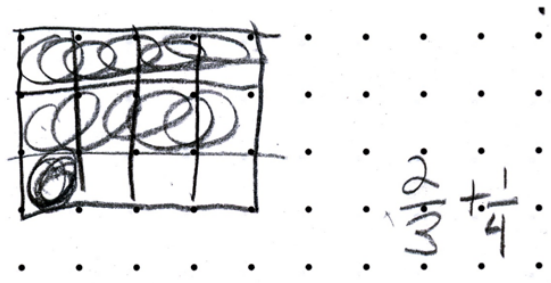

Alison states that the sum is $\frac{9}{12}$.

\section{Explain how you think she got her answer. Describe the main concept that she is misunderstanding.}

8. Draw a picture that illustrates how to multiply $2 \frac{3}{4} \times 4 \frac{3}{5}$.

9. Ms. Brown noticed that her eighth-grade students were having problems making sense of the expression $1 \frac{3}{4} \div \frac{1}{2}$. She decides to write a word problem that illustrates this expression in a real-world context. Write a word problem that Ms. Brown could use.

10. Write a real-world problem that is modeled by the expression $\frac{2}{3} \times \frac{4}{5}$.

11. Three children went to the Guthrie Theater on a field trip and shared eight cookies equally. Eight children chose to go to the Mill City Museum and equally shared 21 cookies. Who received the greater amount of cookie, an individual attending the Guthrie Theater or an individual attending the Mill City Museum? Explain your reasoning.

12. Children will often say that 0.23 is larger than 0.7 because "twenty-three is bigger than seven." Explain how you help your students reason that 0.23 is smaller than 0.7 .

13. a) Draw a picture to show that $\frac{2}{3}$ is equivalent to $\frac{4}{6}$.

b) Students learn that they can generate equivalent fractions by multiplying the numerator and denominator by the same amount (e.g. $\frac{2}{3}=\frac{2 \cdot 2}{3 \cdot 2}=\frac{4}{6}$ ). Explain in general why this is true (i.e. $\frac{a}{b}=\frac{a \cdot c}{b \cdot c}$ ).

c) Students learn that they can reduce fractions by dividing the numerator and denominator by the same amount (e.g. $\frac{4}{6}=\frac{4 \div 2}{6 \div 2}=\frac{2}{3}$ ). Explain in general why this is true (i.e. $\frac{a}{b}=\frac{a \div c}{b \div c}$ ). 